MA ILIJA KUKOBAT, istraživač-stipendista

Institut za savremenu istoriju

Beograd, Republika Srbija

UDK 656.7(497.1)"1945/1947"(093.2)

ilija.kukobat.2012@gmail.com

originalan naučni rad / original scientific paper

primljeno / received: 21. 1. 2020.

prihvaćeno / accepted: 20. 5. 2020.

https://doi.org/10.29362/ist20veka.2020.2.kuk.173-186

\title{
POČECI VAZDUŠNOG SAOBRAĆAJA U POSLERATNOJ JUGOSLAVIJI 1945-1947.
}

APSTRAKT: Na osnovu arhivske građe i literature predstavljena je početna faza u razvoju vazdušnog saobraćaja u Jugoslaviji nakon Drugog svetskog rata, odnosno rad Prvog vazduhoplovnog transportnog puka vazduhoplovstva Jugoslovenske armije u civilnom vazduhoplovstvu do trenutka u kojem se pojavljuju Jugoslovenski aerotransport (JAT) i Jugoslovensko-sovjetsko akcionarsko društvo za civilno vazduhoplovstvo (JUSTA) kao preduzeća kojima je vazdušni saobraćaj predstavljao osnovnu delatnost.

KLJUČNE REČI: Jugoslavija, vazduhoplovstvo, vazdušni saobraćaj, Jugoslovensko ratno vazduhoplovstvo, „Putnik“, Jugoslovenski aerotransport (JAT), Jugoslovensko-sovjetsko akcionarsko društvo za civilno vazduhoplovstvo (JUSTA)

\section{Planovi za obnovu vazdušnog saobraćaja sa kraja Drugog svetskog rata}

Do Drugog svetskog rata, vazdušni saobraćaj na teritoriji Jugoslavije, kao i sa susednim zemljama, obavljalo je Društvo za vazdušni saobraćaj „Aeroput“. Osnovano je 1927. godine kao akcionarsko društvo u privatnom vlasništvu kome je država ugovorom ustupila pravo na obavljanje vazdušnog saobraćaja. Započevši rad sa šest francuskih putničkih aviona na liniji Beograd - Zagreb, „Aeroput“" je postepeno širio svoju flotu i mrežu linija sve do 1940. godine, kada je jugoslovenska vojska rekvirirala deo njegove flote za svoje potrebe. Većina aviona „Aeroputa“ stradala je 1941. tokom Aprilskog rata, dok su dva uspela da se domognu Bliskog istoka, ali su predati na upotrebu britanskom vojnom vazduhoplovstvu. Kraj letačke sezone „Aeroputa“ 1940. godine označio je i kraj jugoslovenskog vazdušnog saobraćaja do 1945 . godine. ${ }^{1}$

\footnotetext{
${ }^{1}$ Više o „Aeroputu“ videti u: Čedomir Krunić, Civilno vazduhoplovstvo Kraljevine Jugoslavije. Knjiga prva (Beograd: izdanje autora, 2010); Чедомир Јанић и Огњан Петровић, Кратка историја ваздухопловства у Србији (Београд: Аерокомуникације, 2011); Bojan Dimitrije-
} 
O potrebi za obnovom vazdušnog saobraćaja na teritoriji Jugoslavije razmišljalo se i pre okončanja Drugog svetskog rata. Jedan od prvih dokumenata na ovu temu sastavljen je već 28. decembra 1944. za potrebe Komisije za privrednu obnovu zemlje (preteče Savezne planske komisije). U ovom planu je iznet predlog mreže putničkih i teretnih vazdušnih linija koje bi uglavnom povezivale glavne gradove republika i veće primorske gradove (putničke), odnosno veće privredne centre (teretne; videti kartu 1). U pogledu nabavke letelica, predložena je nabavka 20 američkih aviona Daglas DC-3, nemačkih Junkers Ju 52 ili sličnog tipa, sa tri tone korisne nosivosti.

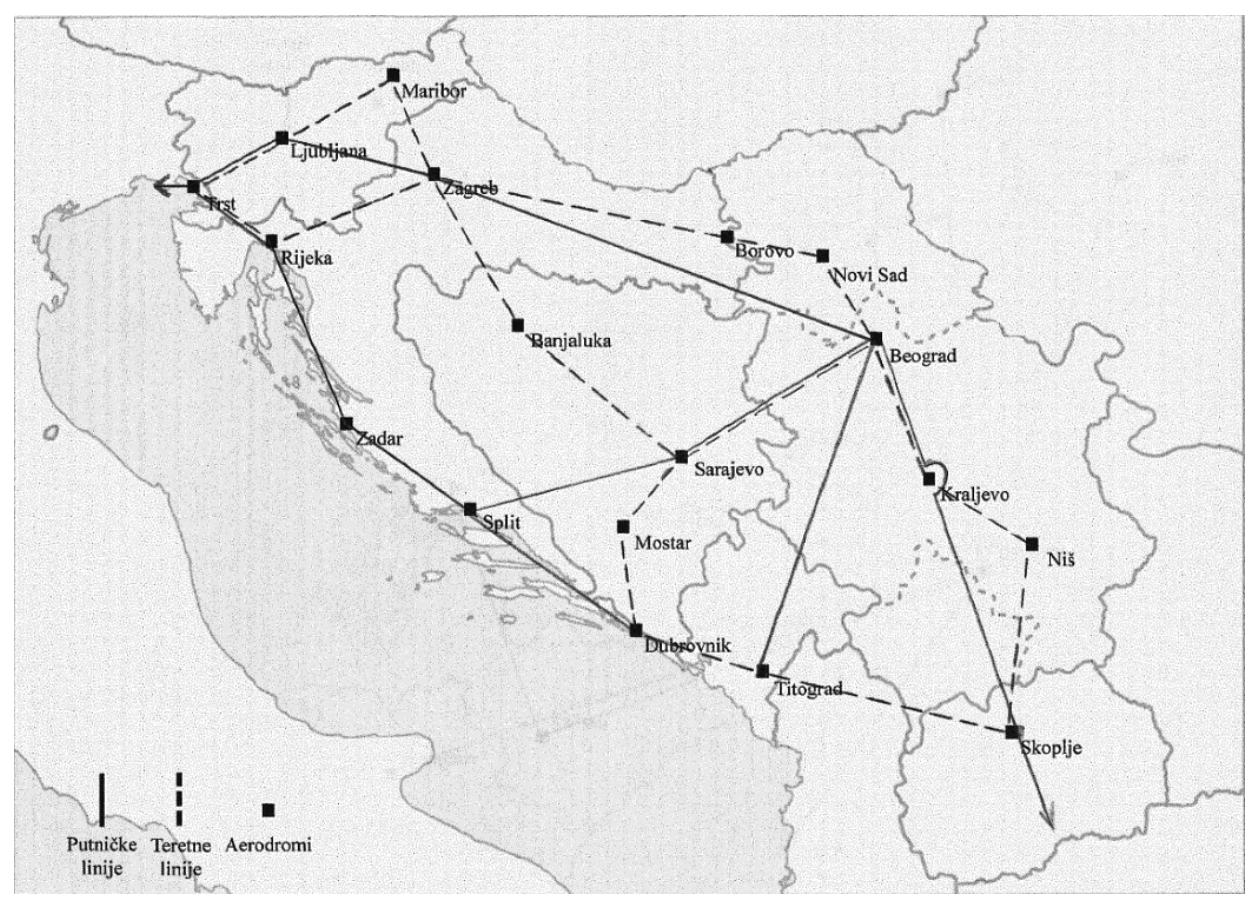

Karta 1: Predložena mreža vazdušnih linija iz 1944.

(Original u: AJ, 41-15-29, Referat o obnovi vazdušnog saobraćaja od 28. 12. 1944)

Pored redovnih linija, preporučeno je da se prema privrednim centrima gde nije predviđena izgradnja aerodroma i održavanje vazdušnog saobraćaja uvedu kurirske linije. Razlog za ovo je bilo očekivanje da će proteći izvesno vreme pre uspostavljanja normalnog drumskog i železničkog saobraćaja prema tim centrima. Kurirski avioni bi prevozili po tri ili četiri putnika, odnosno 200 400 kilograma tereta, a bili bi korišćeni za hitan prevoz alata, opreme, medicinskih sredstava ili putnika od posebnog značaja. Za kurirsku službu predložene su sledeće letelice: nemački „Štorh“, odnosno „Roda“, britanski „Proktor“ i američki „Ferčajld“. Najveći deo ovog referata čine specifikacije potrebne 
opreme i tehničkih sredstava: aviona, rezervnih delova i motora, zemaljske opreme za aerodrome, motornih vozila, pogonskog i potrošnog materijala, kao i detaljne specifikacije opreme i alata za ,konstrukcione, stolarske i finomehaničarske radionice“. Mada ih nema u prvom delu referata, u specifikaciji se pominje i potreba za tri amfibijska aviona ,neodređenog tipa“ $\mathrm{i}$ istog kapaciteta kao kurirski avioni. Najverovatnije bi bili korišćeni na jadranskoj obali i ostrvima. Interesantno je da su se na karti mreže vazdušnih linija kao jugoslovenski gradovi našli i Trst, Zadar i Rijeka, mada rat još nije bio završen. ${ }^{2}$

Uz ovaj, još jedan dokument je, pored detaljne analize rada predratnog Društva za vazdušni saobraćaj „Aeroput“, doneo i neke uopštene predloge za potrebne mere po pitanju obnove vazdušnog saobraćaja. I ovde je konstatovano da bi za potrebe budućeg vazdušnog saobraćaja trebalo nabaviti 10 američkih aviona Daglas DC-3 ili 20 nemačkih aviona Junkers Ju-52, u zavisnosti od toga koji su od njih dostupniji. Sledeća mera bi bilo osposobljavanje osnovnih aerodromskih objekata neophodnih za normalno odvijanje saobraćaja, kao i nabavka uređaja za rad navigacione, meteorološke i službe veze. Konačno, preporučeno je da se prikupi letačko, tehničko, manipulativno i administrativno osoblje, uz napomenu da ga u zemlji ima dovoljno za brzo i efikasno pokretanje vazdušnog saobraćaja. Rečeno je i da vazdušni saobraćaj mora da bude ,uredan, redovan, rentabilan, ekonomski zdrav i siguran“, te da bi trebalo „u tu svrhu povezati i koordinirati sva javna saobraćajna sredstva pod upravu ili kontrolu jednog ministarstva u cilju vođenja jedne opšte saobraćajne politike za celu zemlju. ${ }^{\text {‘3 }}$

Uz ova dva, postojao je i treći, takođe nedatiran plan izložen na nekoliko karata predviđene aerodromske mreže, kao i mreže unutrašnjih i međunarodnih linija, uz spisak potrebnih aviona i druge opreme. Ovde je predložena nabavka jedne transportne divizije sa jednim pukom od 20 dvomotornih aviona $\mathrm{u}$ dve eskadrile i dva puka od po 30 jednomotornih aviona, svaki sa po tri eskadrile. Šest dvomotornih aviona bi bilo korišćeno u međunarodnom saobraćaju, a četrnaest na „unutrašnjoj saveznoj mreži redovnog vazdušnog saobraćaja.“ Jednomotorni avioni bi bili upotrebljeni ,za redovne i vanredne prenose vazdušnim putem nad teritorijama federalnih jedinica.“ Uz ovo, predviđena je nabavka putničkih i teretnih vozila za prevoz putnika, prtljaga, robe i pošte od gradova do aerodroma, kao i opreme za jednu remontnu radionicu na beogradskom aerodromu. U međunarodnom saobraćaju su predviđene tri linije. Prva je bila Moskva - Odesa - Bukurešt - Beograd - Zagreb - Milano - Torino, druga Beograd - Niš - Sofija - Solun - Atina, a treća Beograd - Niš - Skoplje - Solun.

${ }^{2}$ Arhiv Jugoslavije (AJ), fond 41, Savezna planska komisija, fascikla 15, arhivska jedinica 29, Referat o obnovi vazdušnog saobraćaja od 28. 12. 1944. Autor referata nije potpisan.

${ }^{3}$ AJ, fond 836, Kancelarija Maršala Jugoslavije, predmet III-2-c/38, Kratak izveštaj o jugoslovenskoj civilnoj avijaciji. Iako dokument nije potpisan, niti datiran, može se pretpostaviti da je nastao krajem 1945. godine na osnovu sledećeg navoda: „Sada imamo u saobraćaju svega dva

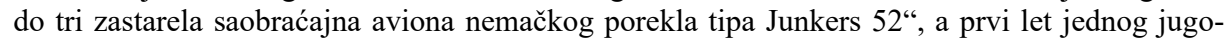
slovenskog putničkog aviona (upravo Ju 52) izveden je 6. oktobra 1945. godine. Odlično poznavanje rada „Aeroputa“ govori da je autor najverovatnije tamo radio pre rata. Verovatno je uz ovaj dokument postojalo propratno pismo sa podacima o autoru i vremenu nastanka dokumenta. 
Na unutrašnjem planu, predviđene su četiri kategorije aerodroma: javna carinska pristaništa I klase (Beograd i Zagreb) i II klase (Niš i Skoplje), kao i javna pristaništa I klase (Ljubljana, Sarajevo i Podgorica) i II klase (Trst, Rijeka, Zadar, Split, Mostar, Dubrovnik i Bar). Mreža linija zamišljena je na sličan način kao i u pomenutom dokumentu dostavljenom Komisiji za privrednu obnovu zemlje uz manje izmene, poput produženja linije Beograd - Podgorica do Bara, tako da je verovatno ovde reč o razradi tog plana. ${ }^{4}$

Konačno, iako nije funkcionisala, na teritoriji Jugoslavije je 1945. još uvek formalno postojala jedna aviokompanija - „Aeroput“. Iako je pod pritiskom okupacionih vlasti u Srbiji 1943. godine doneta odluka o likvidaciji „Aeroputa“, ona je poništena po oslobođenju i 2. jula 1945. održana je vanredna skupština akcionara na kojoj su izabrani novi upravni i nadzorni odbor. Ipak, daljih aktivnosti nije bilo. Konačno, kako se radilo o akcionarskom društvu u privatnom vlasništvu, čije je postojanje bilo suprotno tadašnjem zakonodavstvu, krajem 1948. godine je za svega pet dana (od 24. do 28. decembra) izvršen likvidacioni postupak, čime je „Aeroput“ definitivno prestao da postoji. ${ }^{5}$

\section{Prvi vazduhoplovni transportni puk kao avio-prevoznik}

Već u maju 1945. obavljeni su prvi letovi koji u određenom smislu imaju karakteristike civilnog vazdušnog saobraćaja. Radilo se o službenim putovanjima transportnim avionima vazduhoplovstva Jugoslovenske armije, za koja su izdavane naročite dozvole. Letovi su obavljani od Beograda prema Zagrebu, Zadru, Podgorici, Sarajevu i Bariju. Ipak, ovi letovi nisu imali karakter redovnih avionskih linija, već su obavljani po potrebi, niti je bilo slobodne prodaje karata za građane. Tokom avgusta iste godine bilo je letova i za Ljubljanu, Skoplje, Sofiju, Tiranu, Atinu, Varšavu, Prag, Moskvu i Udine, a na beogradskom aerodromu je bazirana i jedna transportna grupa sovjetskog vojnog vazduhoplovstva. Pored njih, za Beograd su leteli i Amerikanci, Britanci, Francuzi i Bugari. Ipak, čini se da su i ovi letovi bili službene prirode, pošto se opet radilo o vojnim letelicama. ${ }^{6}$

Potreba za brzom i efikasnom vezom sa inostranstvom značila je da će, u nedostatku međunarodnih železničkih veza, vazdušni saobraćaj dobiti prvorazredan značaj. Stoga je prvi vojni avion sa jugoslovenskim oznakama izveo

\footnotetext{
${ }^{4}$ Kopije dokumenata ustupljene ljubaznošću Milana Micevskog. Ovaj plan je sigurno povezan sa pismom Nacionalnog komiteta oslobođenja Jugoslavije pripremljenim za upućivanje Josifu Visarionoviču Staljinu, gde se, pored ostalog, navodi da bi vazduhoplovstvu Jugoslovenske armije trebalo isporučiti tehniku za jednu transportnu diviziju sa jednim pukom od 20 dvomotornih i dva puka sa po 30 jednomotornih aviona, tj. identične količine aviona. AJ, 836, I-3-b/579, Pismo delegata NKOJ-a maršalu J. V. Staljinu, bez datuma (1944/1945?).

${ }^{5}$ O likvidaciji „Aeroputa“ videti: Č. Krunić, $n$. d., 258-269.

${ }^{6}$ Dozvole za službena putovanja avionom videti u: AJ, fond 620, Uprava civilnog vazduhoplovstva, fascikla 1. Najstarija sačuvana molba datirana je 30. 4. 1945; AJ, 620-2, Mesečni izveštaj o radu Vazduhoplovnog pristaništa „Beograd“ za avgust 1945, pov. br. 47 od 20. 9. 1945.
} 
let na liniji Beograd - Prag 6. oktobra 1945. godine. U ovom slučaju, saobraćaj je već bio komercijalne prirode, a prodajom karata, prevozom putnika od grada do aerodroma, smeštajem i kreditiranjem posada čehoslovačkih aviona u Beogradu bavilo se turističko preduzeće „Putnik“. Predlagano je produženje ove linije do Varšave u saradnji sa Čehoslovacima i Poljacima, uz mogućnost zajedničke nabavke aviona, ali do toga nije došlo. U cilju normalnog odvijanja vazdušnog saobraćaja, sklopljen je i međudržavni sporazum između Jugoslavije i Čehoslovačke?

Pored međunarodnog, postojala je potreba i za uspostavljanjem domaćeg vazdušnog saobraćaja, najviše između Beograda i republičkih centara, kao i sa primorjem, do kojeg nisu postojale zadovoljavajuće železničke i drumske veze. U proleće 1946. godine pokrenut je saobraćaj na sledećim linijama: 8 . aprila, Beograd - Titograd i Beograd - Sarajevo; 15. aprila, Beograd - Zadar Zagreb; 7. maja, Beograd - Zagreb; 9. maja, Beograd - Ljubljana; 13. maja, Beograd - Skoplje (videti kartu 2). Pored toga, 11. jula iste godine sklopljen je ugovor o vazdušnom saobraćaju između Jugoslavije i Albanije, a 16. jula otvorena je i druga međunarodna linija, Beograd - Tirana, dok je za upravljanje aerodromom u Tirani osnovan Jugoslovenski centar Glavne uprave vazdušnog saobraćaja (GUVS) FNRJ. Policijsku, carinsku i meteorološku službu obavljali su Albanci, dok su Jugosloveni bili zaduženi za kontrolu letenja, uz zadatak da osposobe albanske kadrove za rad na istim poslovima. Prodajom karata i prevozom putnika od gradova do aerodroma nastavilo je da se bavi turističko preduzeće „Putnik“. Saobraćaj je, međutim, i dalje bio izrazito sezonskog karaktera. Kraj letačke sezone bio je 1 . novembar, budući da kišom raskvašene travnate piste ne bi izdržale težinu aviona, a nepouzdana oprema za odleđivanje na avionima nije garantovala bezbedno letenje, mada su po potrebi vršeni vanredni letovi. Pored toga, Komanda vazduhoplovstva je 23. jula 1946. bez posebnog obrazloženja naredila da se odmah prekine saobraćaj na linijama od Beograda prema Ljubljani, Zagrebu, Sarajevu i Skoplju, kao i na liniji Zagreb - Zadar, mada je kasnije saobraćaj obnovljen u punom obimu. Uz domaće, na jugoslovenske aerodrome i dalje su sletali inostrani avioni: čehoslovački, bugarski, britanski, sovjetski i drugi. ${ }^{8}$

\footnotetext{
${ }^{7}$ AJ, 620-1, Duplikat dopisa „Putnika“ Finansijskom odeljenju Komande vazduhoplovstva od 1. 12. 1945. St/BP 1410; Diplomatski arhiv Ministarstva spoljnih poslova Republike Srbije (DA MSP), Politička arhiva (PA), Jugoslavija, 1945, f. 29, dopisi poslanstva DFJ u Varšavi Ministarstvu inostranih poslova DFJ pov. br. 4651 od 22. 9. 1945. i Odeljenja za vazdušni transport Komande vazduhoplovstva Konzularno-privrednom odeljenju MIP DFJ pov. br. 4990 od 6. 10. 1945.

${ }^{8}$ AJ, fond 7, Putnik, f. 2, Bilten Direkcije „Putnika“, br. 5 za maj 1947; AJ, 41-274-453, Referat uz eksploatacioni plan za 1947. godinu Direkcije civilnog vazdušnog saobraćaja od 12. 12. 1946; AJ, 620-2-4, Mesečni izveštaji uprava javnih vazdušnih pristaništa; AJ, 620-3, Naređenje Komande vazduhoplovstva Glavnoj upravi vazdušnog saobraćaja str. pov. br. 1813. od 23. 7. 1946; AJ, 620-4, Dopis Zemaljske direkcije „Putnika“ za Bosnu i Hercegovinu Komandi vazduhoplovstva br. 839/46 od 27. 7. 1946.
} 


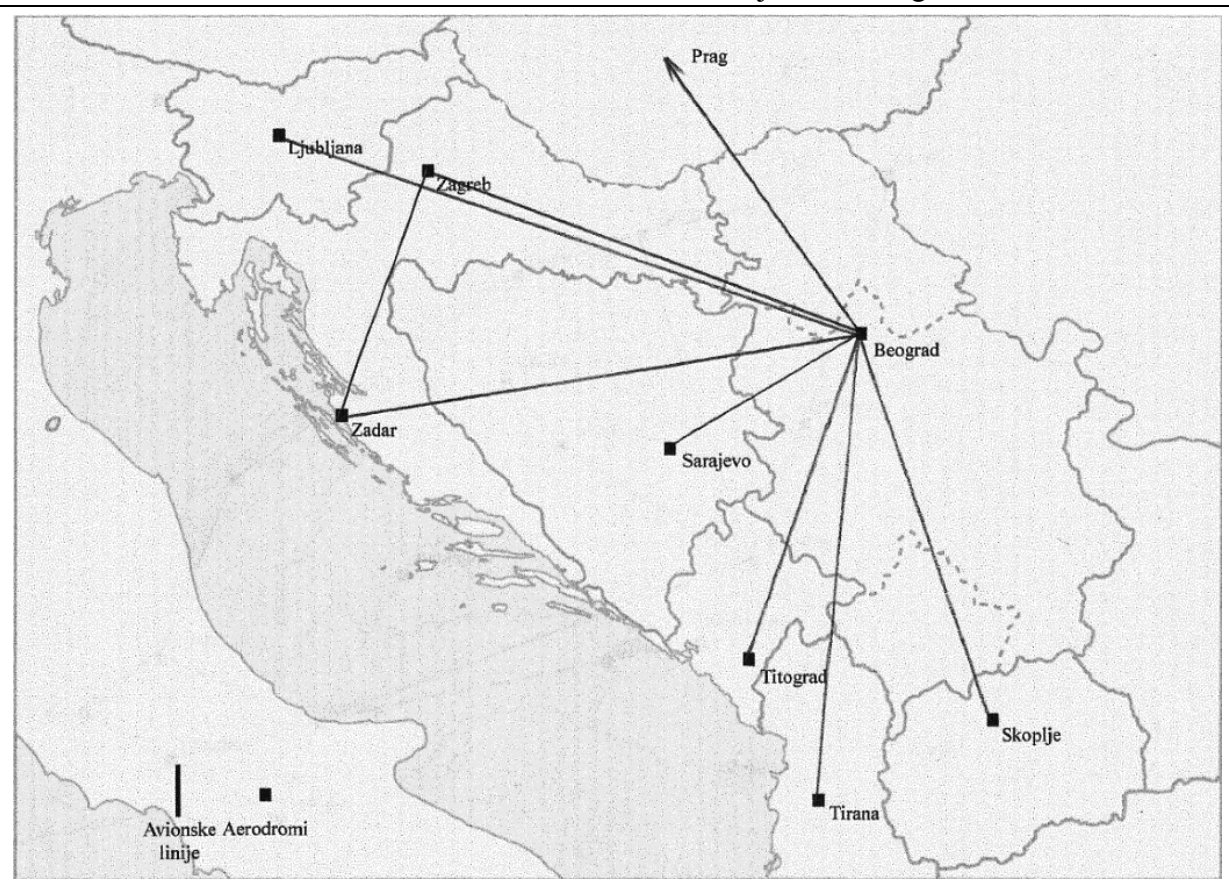

Karta 2: Mreža linija Prvog vazduhoplovnog transportnog puka tokom 1946. godine

(Izrađeno prema: AJ, 7, f. 2, Bilten Direkcije „Putnika“, br. 5, maj 1947)

U trenutku pokretanja vazdušnog saobraćaja, pri Komandi vazduhoplovstva postojalo je Odeljenje za vazdušni transport. Ipak, kao adekvatnije rešenje za upravljanje vazdušnim saobraćajem, u drugoj polovini 1945. formirana je Glavna uprava vazdušnog saobraćaja. ${ }^{9}$ Na njenom čelu se od 1. maja 1946. nalazio generalmajor Đorđe Jovanović, koji je prethodno bio načelnik Odeljenja za vazdušni transport. Iako je formacijski bila u sastavu Komande vazduhoplovstva, finansirana je iz sredstava Ministarstva saobraćaja FNRJ. Pored toga, u rešenju o organizaciji istog ministarstva iz 1946, GUVS se navodi kao organ u njenom sastavu, ali za koji važe posebna organizaciona pravila. ${ }^{10}$ Čini se da je uprava stvarno profunkcionisala tek u maju 1946, kada su postavljeni upravnik i šefovi odseka, doneta pravila o radu i započeto vođenje sopstvenog delovodstva. Pored toga, tek je tog meseca glavni

\footnotetext{
${ }^{9} \mathrm{U}$ dosadašnjem istraživanju nismo uspeli da ustanovimo tačan datum formiranja GUVS. Odeljenje za vazdušni transport Komande vazduhoplovstva obavestilo je Konzularno-privredno odeljenje Ministarstva inostranih poslova DFJ o osnivanju ove uprave dopisom od 13. novembra 1945. bez navođenja datuma osnivanja, tako da bi trebalo da je osnovana nekoliko dana pre toga. Videti: DA MSP, PA, Jugoslavija, 1945, f. 15, pov. br. 6038, 13. 11. 1945. Drugi datumi koji se mogu sresti su 1. 1. 1946. (AJ, fond 162, Ministarstvo saobraćaja Vlade FNRJ, f. 1, Razvoj organizacije rečnog, vazdušnog i drumskog saobraćaja, bez broja i datuma) i 22. 2. 1946. (Bojan Dimitrijević, Jugoslovensko ratno vazduhoplovstvo i protivvazdušna odbrana (Beograd: Institut za savremenu istoriju, 2017), 48).

${ }^{10}$ AJ, 162-1, Rešenje o unutrašnjem uređenju Ministarstva saobraćaja i njegovih ustanova br. 57342/46 od 20. 6. 1946; AJ, 620-2, Naredba Komande vazduhoplovstva pov. br. 82 od 1. 5 1946.
} 
upravnik počeo sa izdavanjem naredbi vezanih za vazdušni saobraćaj, dok se prethodno regulativom bavila direktno Komanda vazduhoplovstva. Uprava je u svom sastavu imala tri odeljenja: Upravno (sa dva odseka: upravni i pravni), Saobraćajno (sa tri odseka: saobraćajni, tarifsko-takseni i statistički) i Finansijsko-komercijalno (sa dva odseka: knjigovodstveno-računovodstveni i materijalni), dok su uprave javnih vazdušnih pristaništa predstavljale posebne organizacione jedinice zadužene za normalno funkcionisanje aerodroma. ${ }^{11}$

Jedina formacija sa letelicama i posadama sposobnim za obavljanje vazdušnog saobraćaja bio je Prvi vazduhoplovni transportni puk. Formiran u avgustu 1945. od Transportne grupe, u svom sastavu je imao sovjetske, nemačke i američke letelice raspoređene u tri eskadrile. Na dan 17. maja 1946. formirana je Transportna eskadrila GUVS kojoj je dodeljen deo ljudstva i tehnike Prvog transportnog puka. Prema predlogu o formiranju eskadrile, upućenom 14. maja te godine, trebalo je da ima komandira, pomoćnika komandira, po jednog administrativnog činovnika i inženjera, po dva tehničara, magacionera i šofera, po osam prvih pilota, drugih pilota, navigatora i radio-telegrafista, kao i 24 mehaničara, odnosno 66 pripadnika. Na raspolaganju bi imala i ,osam višemotornih višeseda“ čiji tip nije naveden. ${ }^{12}$

Kao što je već rečeno, prvi avioni korišćeni u vazdušnom saobraćaju bili su nemački tromotorni transportni avioni tipa Junkers Ju 52. Ovi avioni su konstruisani kao putnički tridesetih godina, da bi u Španskom građanskom ratu bili iskorišćeni kao bombarderi. U Drugom svetskom ratu predstavljali su kičmu nemačke transportne avijacije, iako su smatrani zastarelim. Proizvođeni su i Francuskoj, kako pod nemačkom okupacijom, tako i posle Drugog svetskog rata, pod nazivom ,Tukan“. U vazduhoplovstvu Jugoslovenske armije, odnosno Jugoslovenskom ratnom vazduhoplovstvu, korišćeno je ukupno osam ovih aviona u periodu od 1944. do 1964. godine, od čega četiri originalna nemačka Ju 52, zaplenjena 1944-1945, i četiri francuska „Tukana“. Tri su kupljena 1945. ili 1946. u Francuskoj upravo za potrebe vazdušnog saobraćaja. Pored njih, još dva su nabavljena 1951. za potrebe Jugoslovenskog aerotransporta, pri čemu je jedan uništen iste godine u udesu kod Rijeke, dok je drugi predat Jugoslovenskom ratnom vazduhoplovstvu. ${ }^{13}$

Međutim, kako su letelice sovjetske proizvodnje postale osnov jugoslovenskog vojnog vazduhoplovstva posle Drugog svetskog rata, njima su se ubrzo pridružili sovjetski avioni tipa Lisunov Li-2. Jedanaest ovih aviona primljeno je iz Sovjetskog Saveza avgusta 1945, u vreme mirnodopske reorganizacije i pro-

${ }^{11}$ AJ, 620-2, Naredba Komande vazduhoplovstva pov. br. 82 od 1. 5. 1946; AJ, 620-3, Naredba glavnog upravnika vazdušnog saobraćaja pov. br. 4 od 13. 5. 1946. i Dopis GUVS Trećem odeljenju Komande vazduhoplovstva pov. br. 15 od 13. 5. 1946.

12 AJ, 620-3, Dopis GUVS Trećem odeljenju Komande vazduhoplovstva pov. br. 15 od 13. 5. 1946. i naređenje Komande vazduhoplovstva pov. br. 2688 od 17. 5. 1946.

${ }^{13}$ AJ, 620-3, Depeša GUVS vojnom izaslaniku Jugoslovenske armije u Parizu str. pov. br. 38 od 29. 10. 1946; B. Dimitrijević, $n$. d., 48-49, 417. U depeši se navodi samo da su avioni i delovi isplaćeni, ali ne i kada su prispeli u Jugoslaviju. Ipak, u novembru 1945. pominju se tri registracije aviona ovog tipa, da bi taj broj do septembra 1946. dostigao šest, tako da su verovatno stigli u međuvremenu. 
širenja vazduhoplovstva Jugoslovenske armije. Radilo se o kopiji američkog putničkog aviona Daglas DC-3, verovatno najkvalitetnije letelice u svojoj klasi u tom periodu, za koji su Sovjeti otkupili licencu i koju su uspešno proizvodili uz minimalne razlike u spoljnom izgledu i karakteristikama u letu.

Ipak, ubrzo su počele da pristižu primedbe na „Lisunove“. Pomalo neočekivano za jedan sovjetski avion, smatralo se da je sistem za odleđivanje krila neadekvatan. Najveće probleme, međutim, zadavali su motori. Dolazilo je do čestih kvarova, koristili su drugačije gorivo u odnosu na zapadne letelice i postojala je potreba za posebnim vozilom za startovanje motora, dok su američki motori bili opremljeni električnim starterima. U jednom kasnijem referatu, inž. Ljubomir Golubović naveo je čitav niz nedostataka Li-2 u odnosu na DC-3: manja putna brzina, kraći resurs (vek trajanja) motora i aviona u celosti, slabiji motori, neudobnija putnička kabina, lošija sredstva veze i veća potrošnja goriva. Dalje, smatrao je i da sovjetske tvrdnje o većoj sigurnosti, boljem sistemu zagrevanja kabine, boljoj izradi i dužem veku eksploatacije nisu tačne. Stoga se odustalo od upotrebe Li-2 na međunarodnim linijama, a radilo se na tome da se povuku i iz unutrašnjeg saobraćaja. ${ }^{14}$

Već tokom 1946. godine započela je nabavka američkih transportnih aviona C-47 (prva dva su stigla u proleće 1946), koji su zatim upućivani u čehoslovačku fabriku „Avia“" na preradu u putničke DC-3. Nabavke ovih letelica su obavljane preko Zavoda za vanredne nabavke pri Ministarstvu spoljne trgovine, u čijem se programu nabavki za period od aprila 1945. do decembra 1946. navodi potreba za osam aviona ovog tipa uz rezervne motore i delove. $\mathrm{S}$ druge strane, $\mathrm{u}$ leto 1946. GUVS je preporučila nabavku između šest i deset ovakvih aviona, posebno naglašavajući da se mogu nabaviti veoma povoljno iz američkih viškova u Nemačkoj i Italiji uz adekvatne količine rezervnih delova i motora, kao i da ih čak i Sovjeti koriste na međunarodnim linijama. Procenjeno je da bi nabavka deset aviona sa rezervnim delovima i motorima koštala oko 380.000 dolara. ${ }^{15}$ Već avgusta 1946. pokušana je nova nabavka, ali sada ,iz izvesnih političkih razloga“ Amerikanci nisu hteli da prodaju Jugoslaviji avione. Stoga je u decembru 1946. GUVS predložila Ministarstvu saobraćaja nabavku tri aviona i osam rezervnih motora u Belgiji. ${ }^{16}$ Da se radilo o dobrom izboru najbolje govori činjenica da je DC-3 predstavljao osnovni tip aviona u jugoslovenskom vazdušnom saobraćaju

\footnotetext{
${ }^{14}$ AJ, 620-4, Dopis Uprave vazdušnog javnog carinskog pristaništa „Beograd“ Glavnoj upravi vazdušnog saobraćaja pov. br. 244 od 9. 12. 1946; AJ, 620-56, Mišljenje inž. Ljubomira Golubovića po pitanju poređenja aviona DC-3 sa avionom Li-2. Golubović je postavljen za referenta za avione GUVS 1. 5. 1946 (videti: AJ, 620-2, Naredba Komande vazduhoplovstva pov. br. 83 od 1. 5. 1946), ali druge podatke o njemu do sada nismo našli. Referat nije datiran, ali autor kaže da po pitanju poređenja Li-2 i DC-3 sa tačke gledišta letača treba da se konsultuje „drug [Zlatko] Dimčović“, predratni pilot „Aeroputa“ koji je tokom 1948. godine leteo za JUSTU, gde su se koristili „Lisunovi“. Stoga je ovaj referat verovatno napisan tokom te godine. B. Dimitrijević, $n$. d., 33, 48-49, 418.

${ }^{15}$ AJ, fond 89, Zavod za vanredne nabavke, f. 58, Definitivni program isporuka za pomoć i obnovu Jugoslavije za period 15. aprila 1945-31. decembra 1946; AJ, 620-3, Dopis Komande vazduhoplovstva Generalštabu Jugoslovenske armije pov. br. 173 iz jula 1946 (bez tačnog datuma) i Dopis Komande vazduhoplovstva Konzularno-privrednom odeljenju MIP FNRJ pov. br. 189 od 20. 7. 1946.

${ }^{16}$ AJ, 620-2, Dopis GUVS Ministarstvu saobraćaja FNRJ pov. br. 600 od 10. 12. 1946.
} 
sve do šezdesetih godina 20. veka. Za navedene letelice su propisana sledeća maksimalna dozvoljena opterećenja: Ju 52 - šesnaest putnika, Li-2 - osamnaest putnika, uz petočlanu posadu u oba slučaja. Za DC-3 nismo našli sličan dokument, ali su verovatno imali kapacitet od oko dvadeset putnika. ${ }^{17}$

U trenutku kada je prvi jugoslovenski avion poleteo za Prag, na njemu su se nalazile samo vojne oznake: rondele (kružna oznaka nacionalne pripadnosti letelice, najčešće na krilima ili trupu), državna zastava i eskadrilski broj. Međutim, u novembru 1945. na letelicama počinju da se pojavljuju civilne registracije, kao i određena pravila u njihovom dodeljivanju, koja će se poštovati i kasnije. Za početak, obnovljena je upotreba registarske oznake YU, uvedene 1935. godine, a prve letelice sa civilnim oznakama bila su tri Junkersa: YUCAA, YU-CAB i YU-CAC. ${ }^{18}$ Njima su se zatim pridružili i avioni tipa Li-2 koji su dobijali oznake u sekvenci YU-BA* (zvezdica predstavlja treće slovo u registraciji koje se dodeljuje svakom avionu posebno), a potom i C-47, sa oznakama YU-AB* (kasnije i YU-AC*). ${ }^{19}$ Pored ugovora o vazdušnom saobraćaju sklopljenog sa Čehoslovačkom, jugoslovenske vlasti su morale da traže posebne dozvole od Savezničke kontrolne komisije u Mađarskoj za prelete preko njene teritorije. U zahtevima za izdavanje tih dozvola morali su biti navedeni i znaci pripadnosti letelice, odnosno njihove registracije, koje su služile i kao pozivni znaci za održavanje veze. Što se tiče pravila o označavanju, kasnije su svi putnički avioni u Jugoslaviji dobijali oznake formata YU-A**, pri čemu je drugo slovo dodeljivano po tipu aviona, a treće se odnosilo na konkretan avion.

Kako u dosadašnjem istraživanju nije pronađen jedinstven i celovit spisak letelica koje su upotrebljavane u vazdušnom saobraćaju u ovom periodu, njihova brojnost se može odrediti posredno, kroz druge izvore. Za početak, marta 1946. predviđeno je da se izdvoji pet aviona Prvog transportnog puka za upotrebu u vazdušnom saobraćaju. ${ }^{20}$ Kao što je već bilo reči, do maja je taj broj narastao do osam. Čini se da je taj broj nastavio da raste, jer se u molbama za odobrenje preleta preko Mađarske i mesečnim izveštajima uprava vazdušnih pristaništa navodi ukupno šest registracija za „Junkerse“, od YU-CAA do YU-CAF, i tri registracije za C-47, YUABA, YU-ABB i YU-ABC. ${ }^{21}$ Ovo ukazuje da su sovjetski „Lisunovi“ pretežno korišćeni na domaćim linijama i za povremene vanredne letove ka inostranstvu, što se može pratiti kroz mesečne izveštaje o radu uprava vazdušnih pristaništa, uz koje su prilagani spiskovi aviona koji su koristili određeni aerodrom sa registracijama. Time se, kao i korišćenjem drugih izvora, dolazi do šest Li-2 sa registracijama od

${ }^{17}$ AJ, 620-2, Naredba Komande vazduhoplovstva pov. 110 od 6. 6. 1946. i dodatak istoj naredbi.

${ }^{18}$ DA MSP, PA, Čehoslovačka, 1947, f. 27, pov. br. 5610, Dopis Odeljenja za vazdušni transport Komande vazduhoplovstva pov. VTr. br. 138. od 8. 11. 1945.

19 Ove registracije su korišćene u više navrata. Oznake „Lisunova“ iz Prvog transportnog puka kasnije su ponele letelice JUSTE koje su 1947. pristigle iz Sovjetskog Saveza. Isto tako, letelice C-47 Prvog transportnog puka sa oznakama YU-ABA, YU-ABB i YU-ABC i DC-3 Jugoslovenskog aerotransporta sa istim registracijama nisu isti avioni.

${ }^{20}$ AJ, 620-3, Naredba Komande vazduhoplovstva pov. br. 47 od 21. 3. 1946.

${ }^{21}$ DA MSP, PA, Jugoslavija, 1946, f. 45, Dopis GUVS Konzularno-privrednom odeljenju MIP FNRJ pov. br. 10465 od 2. 9. 1946. 
YU-BAA do YU-BAF, pod pretpostavkom da ih nije bilo više. ${ }^{22} \mathrm{Na}$ osnovu ovoga se može reći da je ukupno 15 aviona Prvog transportnog puka korišćeno u vazdušnom saobraćaju tokom 1946. godine, s tim što nisu svi korišćeni u isto vreme.

Ovde se treba dotaći i sledećeg pitanja: ko je činio posade ovih aviona? Kako u dosadašnjem istraživanju nije pronađen jedinstven spisak letača (pilota, mehaničara-letača, radio-telegrafista, navigatora) Transportne eskadrile GUVS, moramo se osloniti na odluke o upućivanju posada na službena putovanja, kako im je tretiran svaki let. Svi su bili pripadnici Prvog transportnog puka i starešine Jugoslovenske armije. S druge strane, njihovi profesionalni putevi do tog trenutka bili su veoma raznoliki. Među njima je bilo bivših letača „Aeroputa“, zatim bivših oficira i podoficira predratne jugoslovenske vojske, od kojih su neki tokom Drugog svetskog rata bili pripadnici kvislinških formacija, kao i učesnika Drugog svetskog rata iz redova Narodnooslobodilačke vojske, bivših pripadnika Grupe vazduhoplovnih divizija koja je dejstvovala nad Sremskim frontom i dve eskadrile formirane u sastavu britanskog Kraljevskog vazduhoplovstva. Neki od njih su prebačeni u transportnu avijaciju zbog prethodnog iskustva sa civilnim saobraćajem, dok se u nekim slučajevima radilo o nastojanju da se iz vojske uklone kadrovi koji bi se mogli smatrati nepodobnim. Posade su najčešće bile petočlane, a činili su ih prvi pilot, drugi pilot, mehaničar-letač, navigator i radio-telegrafista. ${ }^{23}$

Pored letačkog, značajna pažnja je ukazivana zemaljskom osoblju. U februaru i martu 1946. organizovan je tečaj za usavršavanje rukovodilaca uprava vazdušnih pristaništa, pri čemu je program obuhvatao sledeće predmete: međunarodno zakonodavstvo (17 časova), domaće zakonodavstvo (17), vazdušni saobraćaj (24), službu veze i obaveštavanja (18), meteorološku službu (19), kontrolu letenja (16), pristanišnu službu i administraciju (21), ali i političko vaspitanje (18). Kurs je vodio kapetan Stanislav Kamenšček, upravnik beogradskog aerodroma, a pohađali su ga upravnici, pomoćnici upravnika i saobraćajni činovnici uprava vazdušnih pristaništa. ${ }^{24}$ Postojala je i određena kategorizacija aerodroma u više redova, što se odnosilo i na broj osoblja na aerodromu. Primera radi, predviđena formacija vazdušnog pristaništa drugog reda obuhvatala je 14 ljudi: upravnika, pomoćnika upravnika, saobraćajnog činovnika, lekara, daktilografa, domara, bolničara, dva šofera, kurira, čistačicu i dva nosača. Upravnik i njegov pomoćnik su bili oficiri, kurir vojnik, a ostali građanska lica. ${ }^{25}$

${ }^{22} \mathrm{U}$ mesečnim izveštajima sa više aerodroma pominju se letelice Li-2 sa oznakama YU-BAA, YU-BAB, YU-BAD i YU-BAE (videti: AJ, 620-3; AJ, 620-4). Uz to, na jednoj fotografiji sa beogradskog aerodroma nastaloj u leto 1946. vide se letelice sa oznakama YU-BAA, YU-BAC, YU-BAE i YU-BAF (B. Dimitrijević, $n$. d., 38). Presekom ovih izvora dolazimo do ukupno šest aviona Li-2 koji su sigurno nosili civilne registracije.

${ }^{23}$ Naredbe o službenim putovanjima letača videti u: AJ, 620-2; AJ, 620-3. Personalije za deo službenika GUVS (letača i administrativnog osoblja) videti u: AJ, 620-4.

${ }^{24}$ AJ, 620-2, Dopis rukovodioca kursa za usavršavanje rukovodećeg osoblja [...] Odeljenju za vazdušni transport Komande vazduhoplovstva br. 55 od 28. 1. 1946; AJ, 620-3, Naredba Komande vazduhoplovstva pov. br. 8 od 24. 1. 1946.

${ }^{25}$ AJ, 620-3, Raspis GUVS upravama vazdušnih pristaništa drugog reda str. pov. br. 4 od 4. 6 . 1946. Nažalost, u dokumentima nije bilo slične formacije za druge kategorije aerodroma, niti pojašnjenja njihove kategorizacije. 
Podrazumeva se da nisu svi letovi tekli bez problema, bez obzira na kvalitet letelica i sposobnost letača i drugog osoblja. Za početak, dešavalo se da budu otkazani zbog lošeg vremena ili različitih kvarova. Dalje, primljen je čitav niz primedbi pilota koji su smatrali da su mogli da polete ili slete na neki aerodrom iako im je kontrola letenja to zabranila usled meteoroloških uslova. Dešavalo se i da u avion bude ukrcan veći broj putnika od dozvoljenog. U cilju povećavanja bezbednosti saobraćaja, avijacijskim jedinicama vazduhoplovstva Jugoslovenske armije raspoređenim na aerodrome koje su koristili i putnički avioni naređeno je da ne smeju da vrše probne letove u vreme kada se očekuje sletanje ili poletanje putničkih aviona. ${ }^{26}$ Daleko ozbiljniji incident desio se 11. aprila 1946, kada su sovjetski lovci primorali jugoslovenski putnički avion na liniji Beograd - Prag da sleti na aerodrom Papa u Mađarskoj. Obrazloženje je bilo da je leteo kroz zabranjenu zonu, ali mu je posle pregleda letelice, posade i putnika dozvoljeno da nastavi let. Kasnije se pokazalo da jugoslovenska posada nije letela kroz zabranjenu zonu. ${ }^{27} \mathrm{~S}$ druge strane, neke žalbe na prvi pogled mogu delovati komično. Primera radi, putnici na jednom letu iz Zadra za Beograd žalili su se na nesnosan miris ribe i rakova koji su prevoženi u putničkoj kabini aviona, neupakovani i nerashlađeni. ${ }^{28}$

Verovatno najekstremniji slučajevi ometanja vazdušnog saobraćaja dešavali su se u Titogradu. Odande su stigle žalbe na ponašanje jednog oficira Odeljenja za zaštitu naroda koji je najmanje jednom sebi dao za pravo da ukrcava i iskrcava putnike po svojoj volji, zahtevajući čak i povratak aviona koji je već odleteo za Beograd, kao i da preti i privodi aerodromske službenike zato što su mu se protivili. GUVS je po ovom pitanju zahtevala intervenciju nadležnih organa NR Crne Gore uz pretnju da će, ukoliko se ovakvi ispadi nastave, otkazati letove na liniji Beograd - Titograd. Mada nismo našli odgovor na ove žalbe, jedno je svakako izvesno: linija nije ukinuta. ${ }^{29}$

\section{Ulazak u redovne tokove: početak rada JAT-a i JUSTE}

Iako je vazdušni saobraćaj tokom 1946. godine funkcionisao zadovoljavajuće, bilo je jasno da Prvi transportni puk, kao vojna jedinica, ne može da se bavi vazdušnim saobraćajem duže vreme. Pored toga, sam naziv organa zaduženog za vazdušni saobraćaj, Glavna uprava vazdušnog saobraćaja, bio je netipičan za Komandu vazduhoplovstva, koja se delila na odeljenja. Uostalom, sam naziv je dodeljen tako da bude ,u saglasnosti sa odgovarajućim Glavnim upravama saobraćajnih nadleštava pod Ministarstvom saobraćaja. Ovo tim više, što će u najskorije vreme Glavna uprava vazdušnog saobraćaja biti uključena i pot-

${ }^{26}$ AJ, 620-2, Naređenje Komande vazduhoplovstva pov. br. 5694 od 11. 10. 1946.

${ }^{27}$ AJ, 620-2, Izveštaj kapetana Milivoja Arsenijevića komandi 1. transportnog puka od 12. 4. 1946. i dopis Ministarstva inostranih poslova FNRJ Komandi vazduhoplovstva pov. br. 4512 od 24. 4. 1946.

${ }^{28}$ AJ, 620-3, Dopis Uprave vazdušnog javnog carinskog pristaništa „Beograd“ Glavnoj upravi vazdušnog saobraćaja pov. br. 120 od 13. 6. 1946.

29 AJ, 620-3, Dopis upravnika vazdušnog pristaništa „Podgorica“ Slavka Simića Odeljenju za zaštitu naroda Komande vazduhoplovstva od 20. 6. 1946. i prepis dopisa Komande vazduhoplovstva Predsedništvu Vlade NR Crne Gore, pov. br. 152 od 6. 7. 1946. 
padati ovde citiranom ministarstvu. “30 Konačno, GUVS se već tokom 1946. navodi kao organizaciona celina Ministarstva saobraćaja FNRJ. Sve ovo jasno govori da je vazdušni saobraćaj u prvo vreme prepušten vojnom vazduhoplovstvu zato što je jedino ono imalo mogućnosti da se time bavi u datom trenutku, kao i da se očekivalo da bude prenet u civilnu nadležnost čim se za to steknu uslovi. Stoga se tokom 1946. godine radilo na pronalaženju odgovarajuće organizacione forme za budući razvoj jugoslovenskog vazdušnog saobraćaja, kako na unutrašnjem, tako i na međunarodnom planu.

Novembra 1946. formirana je u okviru GUVS Direkcija civilnog vazdušnog saobraćaja, koja je u tom trenutku raspolagala sa pet aviona, tri Ju-52 i dva C-47. Planiralo se da sa saobraćajem počne 1. aprila i da letačka sezona potraje do 1. novembra 1947. iz već pominjanih razloga, kao i da se održava šest domaćih i tri međunarodne linije. Ukupno bi imala 105 službenika, i to 30 letača, 24 tehničara za održavanje aviona, 12 tehničara u radionici i 39 administrativnih radnika. ${ }^{31}$ Direkcija nije zamišljena kao privredno preduzeće, već samo kao organizaciona jedinica GUVS. Planovi i najave početka njenog rada pod tim imenom mogu se sresti sve do marta 1947. godine, kada se prvi put u dokumentima nailazi na drugi naziv za ovu Direkciju - Jugoslovenski aerotransport (JAT). Ipak, ostaje nerazjašnjeno ko je i kada tačno prvi put predložio ovaj naziv. Naime, u trenutku kada nailazimo na prvi pomen naziva JAT, on ni na koji način nije dodatno pojašnjen, tako da se može reći da je već bio poznat i prihvaćen. Razlog za njegovo korišćenje najverovatnije leži u tome što je znatno jednostavniji nego Direkcija civilnog vazdušnog saobraćaja. ${ }^{32} \mathrm{Uz}$ to, sa Sovjetskim Savezom su tokom 1946. vođeni pregovori o osnivanju mešovitih privrednih društava, između ostalih i Jugoslovensko-sovjetskog akcionarskog društva za civilno vazduhoplovstvo JUSTA. ${ }^{33}$

U formalnom smislu, GUVS je 1. februara 1947. iz sastava Komande vazduhoplovstva prešla u Ministarstvo saobraćaja FNRJ. Promenjen joj je naziv, tako da je sada funkcionisala kao Glavna uprava civilnog vazdušnog saobraćaja, a njen upravnik postao je Mladen Šneler. Izmenjena je i njena unutrašnja struktura, tako da je sada imala sekretarijat i sledeće sektore: Kadrovski, Komercijalni, Planski, Sektor eksploatacije i Upravu pristanišne službe i obezbeđenja. Posle toga, u nekoliko navrata je obavljena demobilizacija dela pripadnika Prvog transportnog puka, kao i izdvajanje jednog dela letelica. Nakon dugotrajnih pregovora, 4. februara 1947. potpisan je međudržavni ugovor o osnivanju JUSTE.

${ }^{30}$ AJ, 620-4, Dopis Komande vazduhoplovstva Generalštabu Jugoslovenske armije pov. br. 923 od 19. 2. 1946.

${ }^{31}$ AJ, 41-274-453, Referat uz eksploatacioni plan za 1947. godinu Direkcije civilnog vazdušnog saobraćaja od 12. 12. 1946.

32 AJ, 7-2, Bilten Direkcije „Putnika“ br. 3 za mart 1947; AJ, 620-5, Dopis GUVS Planskom odeljenju Ministarstva saobraćaja pov. br. 123 od 15. 3. 1947.

33 Više o osnivanju JUSTE: Чедомир Крунић, „Југословенско-совјетско акционарско друштво за цивилно ваздухопловство ЈУСТА“, Лет: часопис за историју ваздухопловства, бр. 2, (2000), 127-130; Milan Gulić i Momir Ninković, „Mješovita jugoslovenskosovjetska društva. Slučaj JUSTE“, Istorija 20. veka, XXXII, br. 1, (2014), 143-150. 
Početak nove letačke sezone 1. aprila 1947. doneo je početak rada JATa. Ipak, za sada nemamo konkretnih dokaza da su se na putničkim letelicama baš tog dana pojavile i njegove oznake. Uz to, formalno rešenje Vlade FNRJ o osnivanju JAT-a kao preduzeća doneto je tek 27. aprila 1948. godine, tako da je on do tog trenutka u suštini funkcionisao kao organizaciona jedinica GUVS. Sa svoje strane, JUSTA je sa radom otpočela po prijemu prvih letelica iz Sovjetskog Saveza jula 1947. godine. ${ }^{34}$

$\mathrm{Na}$ prvi pogled, rezultati rada Prvog transportnog puka mogu delovati skromno. U periodu dok je obavljao delatnost civilnog vazdušnog saobraćaja, prema dostupnim podacima, njegovim letelicama je prevezeno oko 10.000 putnika i 100 tona tereta. Do sasvim tačnih podataka o ovom pitanju nije moguće doći. Neki od izveštaja aerodromskih uprava dostavljani GUVS su kompletni, sa statističkim pregledima naplaćenih taksi, prodatih karata, putnika i robe, kao i spiskovima aviona uz registracije. Negde ima samo izveštaja bez statistike, a ima i slučajeva da za neke mesece uopšte nema izveštaja za pojedine aerodrome. ${ }^{35}$ Pored toga, teško je odrediti ko je tačno putovao avionima Prvog transportnog puka. Stiče se utisak da se i ovde uglavnom radilo o službenim putovanjima, iako je tokom 1946. bilo slobodne prodaje karata, a saobraćaj je dobio komercijalni karakter. Ipak, treba imati na umu da je ovaj puk obavljao vazdušni saobraćaj pored vršenja svojih osnovnih zadataka u svojstvu transportne jedinice vojnog vazduhoplovstva. Iako je bilo potrebno još neko vreme da se regulišu odnosi u jugoslovenskom civilnom vazduhoplovstvu, prva polovina 1947. godine može se smatrati makar simboličnim početkom regularnog funkcionisanja vazdušnog saobraćaja u socijalističkoj Jugoslaviji.

\section{REFERENCE}

- Dimitrijević Bojan, Milan Micevski, i Predrag Miladinović. Kraljevsko vazduhoplovstvo. Vojno vazduhoplovstvo Kraljevine SHS/Jugoslavije 1918-1944. Beograd: Institut za savremenu istoriju, 2012.

- Dimitrijević, Bojan. Jugoslovensko ratno vazduhoplovstvo i protivvazdušna odbrana. Beograd: Institut za savremenu istoriju, 2017.

- Gulić Milan, i Momir Ninković. „Mješovita jugoslovensko-sovjetska društva. Slučaj JUSTE“. Istorija 20. veka, XXXII, br. 1, (2014), 143-163. https://doi.org/10.29362/ist20veka.2014.1.gul.143-164

- Janić Čedomir, i Ognjan Petrović. Kratka istorija vazduhoplovstva u Srbiji. Beograd: Aerokomunikacije, 2011.

34 AJ, fond 50, Predsedništvo Vlade FNRJ, fascikla 85, arhivska jedinica 181, prepis rešenja Vlade FNRJ o osnivanju Jugoslovenskog aerotransporta br. 3062/48 od 27. 4. 1948; AJ, 162-1, Razvoj organizacije rečnog, vazdušnog i drumskog saobraćaja, bez broja i datuma; AJ, 620-5, Izveštaj GUVS Sekretarijatu Ministarstva saobraćaja FNRJ pov. br. 168. od 18. 4. 1947; Ч. Крунић, JУCTA, 133-134; M. Gulić, M. Ninković, $n$. d., 150-151; B. Dimitrijević, $n$. d., 49.

${ }_{35}$ Mesečne izveštaje videti u: AJ, 620, f. 3-4. Ovde su upotrebljeni podaci Zavoda za statistiku: Жељко Лесић и др., Превоз путника и робе у СР Југославији 1946-1996. Кориговани и процењени подаци по гранама саобраћаја (Београд: Савезни завод за статистику, 1999) $56-57,61$. 
- Krunić, Čedomir. „Jugoslovensko-sovjetsko akcionarsko društvo za civilno vazduhoplovstvo JUSTA“. Let: časopis za istoriju vazduhoplovstva, br. 2, (2000), 127-151.

- Krunić, Čedomir. Civilno vazduhoplovstvo Kraljevine Jugoslavije. Knjiga prva. Beograd: izdanje autora, 2010.

- Lesić Željko, Olga Melovski-Trpinac, Olga Cvetanović, Mira Zarić, i Gordana Bogosavljević. Prevoz putnika i robe u SR Jugoslaviji 1946-1996. Korigovani i procenjeni podaci po granama saobraćaja. Beograd: Savezni zavod za statistiku, 1999.

MA ILIJA KUKOBAT, Research Grantee

Institute for Contemporary History

Belgrade, Republic of Serbia

ilija.kukobat.2012@gmail.com

\section{THE BEGINNINGS OF AIR TRANSPORTATION \\ IN POSTWAR YUGOSLAVIA 1945-1947}

\section{Summary}

Before World War II, a domestic company called "Aeroput" operated Yugoslavia's domestic and international airlines. After the war, the airlines could not be reestablished for two major reasons: they had lost nearly all of their assets during the war and they were a privately-owned company, meaning they would not be allowed to operate in a socialist economy. Due to an urgent need for a fast and reliable connection between Belgrade and the capital cities of the Yugoslav republics, its coastal area, and the outside world, the authorities decided to use the planes of the Yugoslav Air Force First Transport Regiment as a replacement for an actual airline company. As an administrative body, the Main Directorate of Air Transportation was formed within the Air Force Command, although it was financed by the Yugoslav Transportation Ministry. The "Putnik" travel agency was tasked with selling tickets and accommodating passengers. During 1946, using around fifteen aircraft of three different types (Ju 52, Li-2, DC-3), the Main Directorate's Transport Fleet managed to transport around 10,000 passengers and 100 tons of mail and cargo on six domestic and two international routes. In early 1947, the Main Directorate of Air Transportation, its aircraft and employees, were transferred to the Transportation Ministry. In addition, two airline companies were formed, the state-owned Yugoslav Airlines (YAT) and the Yugoslav-Soviet Civil Aviation Company (YUSTA), which signaled the beginning of a new phase in the development of civil aviation in Yugoslavia.

KEYWORDS: Yugoslavia, Aviation, Air Transportation, Yugoslav Air Force, Putnik, Yugoslav Airlines (YAT), Yugoslav-Soviet Civil Aviation Company (YUSTA) 